Dr SRĐAN CVETKOVIĆ, viši naučni saradnik

Institut za savremenu istoriju

Beograd, Trg Nikole Pašića 11

scvetkovic72@gmail.com

Dr DRAGOMIR BONDŽIĆ, viši naučni saradnik

Institut za savremenu istoriju

Beograd, Trg Nikole Pašića 11

dragomirbondzic@ptt.rs

pregledni rad

UDK 323.269.3:378.18(497.11)"1945/1990"

primljeno: 6. april 2016.

316.75:378(497.11)"1945/1990"

prihvaćeno: 23. novembar 2016.

\title{
OBLICI STUDENTSKOG OTPORA KOMUNISTIČKOM REŽIMU U SRBIJI 1945-1990.
}

APSTRAKT: Rad donosi presek i analizu svih oblika studentskog otpora komunističkom režimu u Srbiji od 1945. do 1990. Otpor revolucionarnim vlastima, koji je slomljen represijom u prvim godinama posle Drugog svetskog rata, bio je pritajen tokom pedesetih da bi se razvio od druge polovine šezdesetih a kulminirao u godinama posle smrti Josipa Broza Tita. Najveći intenzitet aktivnog društvenog otpora u samoupravnom socijalizmu dostignut je u periodu 1966-1972. i zatim 1981-1990. Krajem 60-ih stasavaju nove generacije obrazovane posle rata koje traže svoj politički izraz. Pobuna "prekobrojnih" poratnih generacija, radikalni studentski pokreti i demonstracije, turbulencije u svetu (ratovi i terorizam), efektom "grudve snega" podizali su temperaturu u zemlji. Osim generacijskog bunta, tome su išli na ruku kampanja liberalizacije posle 1966. (pad Aleksandra Rankovića), relativno slabljenje autoriteta države, Partije i službe bezbednosti i smrt Josipa Broza kao nosećeg stuba režima. Globalna kriza komunizma 80-ih, ali i galopirajuća ekonomska kriza u SFRJ podsticala je intenzitet otpora.

KLJUČNE REČI: komunizam, studenti, Srbija, javni protesti, demonstracije, štrajkovi, pobune

\section{Studenti i „nova vlast“ 40-ih godina}

Uzimajući u obzir da posle Drugog svetskog rata u uslovima uspostavljanja jednopartijske diktature u Srbiji i Jugoslaviji nije postojala sloboda izražavanja mišljenja, javnih manifestacija kao ni sloboda štampe i medija, 
na prvi pogled u periodu 1944-1953. nije bilo značajnih javnih demonstracija nezadovoljstva protivnika režima. Ovenčana oreolom predvodnika u borbi sa fašizmom u atmosferi strahovlade, Komunistička partija Jugoslavije je bez sumnje imala relativno najveću podršku u narodu u odnosu na druge komunističke partije u Istočnoj Evropi. To, međutim, ne znači da prilikom revolucionarnog preobražaja društvene strukture i uspostavljanja jednopartijske diktature nije bilo brojnih i ozbiljnih otpora. Dublja analiza pokazuje znatnu represiju prema gore naročito kod određenih slojeva građanstva, učenika i studenata, seljaštva, crkve ili pak unutarpartijskih struktura u vreme Informbiroa (IB) i kasnije. Većim delom su ove manifestacije imale pasivan indirektan karakter, jedino se u određenim prelomnim trenucima otpor ispoljavao kao aktivan i delimično organizovan. Otpor novom komunističkom režimu naročito je bio snažan posle rata, $u$ vreme stabilizacije vlasti i faktičkog gašenja višepartijskog sistema 1945-1946, zatim u početku sprovođenja petogodišnjeg plana 1947. i u doba kulminacije sukoba sa Staljinom i ubrzane kolektivizacije. U prvom periodu nosilac otpora $\mathrm{u}$ Srbiji bili su preostalo građanstvo i odmetnuti pripadnici i simpatizeri poraženih snaga $u$ građanskom ratu, dok je u vreme otkupa i kolektivizacije to bilo krupno seljaštvo, zatim posle Rezolucije IB određene unutarpartijske strukture.

U posleratnom periodu studenti su predstavljali važnu ciljnu grupu Komunističke partije. Od njih je trebalo stvoriti „novu socijalističku inteligenciju“, priklonjenu politici i ideologiji vladajuće Partije, i nosioca političkih, društvenih, ekonomskih, kulturno-prosvetnih reformi i razvoja. U skladu s tim, Partija je posle rata posmatrala univerzitete i fakultete kao "fabrike kadrova“ i poklanjala je veliku pažnju porastu broja visokoškolskih ustanova i studenata (u Srbiji je od 1945. do 1960. broj fakulteta porastao sa 9 na 29, a broj studenata sa oko 14.000 na skoro 70.000), sadržaju planova, programa, udžbenika i literature, nastavnom kadru, materijalnom položaju, kulturnom i svakodnevnom životu studenata, a posebno njihovom ideološko-političkom opredeljenju i ponašanju. Na fakultetima su već 1945, po godinama i studijskim grupama, formirane razgranate partijske i studentske organizacije koje su, uz ostalo, imale zadatak da pažljivo nadziru, kontrolišu i oblikuju ideološke i političke stavove studenata prema vladajućem režimu i da vrše stalan ideološko-politički i agitaciono-propagandni pritisak na njih. ${ }^{1}$

Međutim, i pored toga, veliki broj studenata i dalje nije odgovarao stavovima vladajuće Partije, bilo građanskim poreklom, bilo stvarnom ili

${ }^{1}$ Više u: Dragomir Bondžić, Beogradski univerzitet 1944-1952 (Beograd: ISI, 2004); Исти, Универзииеей у соиијализму. Високо школсшиво у Србији 1950-1960 (Београд: ИСИ, 2010). 
navodnom bliskošću i saradnjom sa okupatorom ili komunistima suprotstavljenim pokretima tokom rata, bilo ponašanjem i odnosom prema novim vlastima i ideologiji i politici Komunističke partije. Radom partijskih i policijskih organa, kao i dojavama samih studenata, otkrivani su različiti „neprijatelji" koji su potom isključivani iz studentske organizacije (Narodna studentska omladina - NSO), uklanjani sa fakulteta, a ponekad i hapšeni. Među njima su bili studenti koji su se okupljali u manjim grupama, raspravljali o politici, cepali partijske i studentske plakate i parole, bacali antipartijske letke, širili glasine o promeni stanja u zemlji, pričali viceve i „klevetali“ državno rukovodstvo, bojkotovali studentske konferencije i predavanja profesora komunista, itd. Oni su označavani kao „dražinovci“, „grolovci“, „dragoljubovci“, „reakcionari“, „buržuji“, „fašisti“, „, nenarodni elementi“, itd. I veličanje zapadnih demokratskih zemalja, zapadne kulture i umetnosti, odlazak u njihove ambasade i čitaonice, slušanje Radio Londona i Glasa Amerike, smatrano je oblikom otpora režimu i neprijateljskom delatnošću. ${ }^{2}$

Jedan deo studenata je održavao veze i učestvovao $u$ aktivnostima ilegalnih antikomunističkih, nacionalnih, demokratskih, građanskih omladinskih organizacija koje su se zalagale za restauraciju građanskog poretka i koje su do početka 50 -ih godina u velikoj meri razbijene a njihovi pripadnici, uglavnom srednjoškolci i studenti, pohapšeni i osuđeni (Nacionalna revolucionarna studentska omladina (NRSO) - 1946, Beli orlovi - 1948, Savez demokratske omladine Jugoslavije (SDOJ) - 1949, Omladina Demokratske stranke (ODES) - 1950, Antikomunistička omladina Jugoslavije (AKOJ), Demokratska omladina Srbije (DOS) i druge). Na procesu SDOJ maja 1949. godine 12 omladinaca, mahom gimnazijalaca, osuđeno je na 122 godine zatvora. Optuženi Borislav Pekić tada student istorije umetnosti dobio je 10, a kada se žalio Vrhovnom sudu Srbije osuđen je čak na 15 godina. Delovanje ovih grupa je uglavnom bilo propagandno-političkog karaktera: rasturanje i štampanje letaka, pisanje parola, propaganda protiv društvenog uređenja i NOP-a i sl., anonimne pretnje i pisma komunističkim funkcionerima, sitne diverzije i sabotaže privrednih mera, jatakovanje ravnogorskim odmetnicima, dopisivanje i povezivanje sa emigracijom i drugo. Vremenom se omladinski radikalizam stišavao, a novi revolucionari su se nevoljno uklapali u sistem posle izdržanih kazni. ${ }^{3}$

${ }^{2}$ D. Bondžić, Beogradski univerzitet 1944-1952, 298-308.

${ }^{3}$ Arhiv Jugoslavije (AJ), Državna komisija za utvrđivanje zločina okupatora i njihovih pomagača, 110-824-1041; Isto, Popis optužnica i presuda; Димитрије Ђорђевић, Ожиљии и ойомене III (Београд: СКЗ, 1999), 233; Угљеша Крстић, Нейрисйајање (Београд: Вајат, 2004), 102; Borislav Pekić, Godine koje su pojeli skakavci III (Beograd: BIGZ, 1991). 
U međuvremenu se krajem 40-ih godina među studentima pojavila još jedna grupa nezadovoljnika i „protivnika“ režima, ovaj put iz redova same Komunističke partije. Reč je o studentima koji su u velikom ideološkom sukobu jugoslovenske i sovjetske partije 1948. stali na stranu Sovjetskog Saveza i Informbiroa. Već tokom leta 1948. na partijskim sastancima na fakultetima izvestan broj studenata se izjasnio za Rezoluciju Informbiroa, što je dovelo do oštre reakcije partijskih organa i UDB-e, isterivanja iz Partije i sa fakulteta, hapšenja, pa i odvođenja na Goli otok. Već do oktobra 1948. za Informbiro se izjasnilo 350 studenata Beogradskog univerziteta, a do kraja 1949. iz Partije je isključeno 495 studenata „ibeovaca“, od čega je više od polovine uhapšeno, a neki upućeni na „društveno koristan rad u preduzeću Mermer“, odnosno na Goli otok. „Ibeovci“ su i narednih godina širili „neprijateljsku propagandu“, brošure i letke Informbiroa, ispisivali parole, slušali informbirovske radio-stanice, vršili sabotaže, „klevetali narodu vlast", itd., a protiv njih su i dalje preduzimane različite represivne mere, kao i ideološko-politički pritisak. Istovremeno, korišćena je prilika da se kažnjavaju i studenti koji su smatrani „reakcionarima“, „bivšim četnicima“, „nedićevcima“, „ljotićevcima“ i koji su prema mišljenju Partije koristili sukob sa Informbiroom i jačali svoju delatnost „protiv narodne vlasti“.

\section{„Pobuna gladnih“ - studentski protesti i štrajkovi 50-ih godina}

Do polovine 50 -ih godina Partija je represivnim merama uspela da slomi sve vidove aktivnog otpora. S druge strane liberalizacijom režima i postepenim rastom standarda, zadobijanjem podrške na Zapadu i normalizacijom odnosa sa Istokom, intenzitet unutrašnjeg otpora se postepeno topio. I pored nesumnjivo veće prihvaćenosti režima posle 50 -ih, istraživanja ukazuju na tinjanje "tihog otpora“ naročito kod određenih struktura stanovništva (ostataka starog građanstva, crkvenih struktura, studenata, u redovima advokata i simpatizera IB-a itd.). Težište aktivnog otpora kroz propagandnu, ali i drugu čak i terorističku delatnost pomerilo se ka političkoj emigraciji. ${ }^{5}$

Početkom 50-ih godina među beogradskim studentima je sve više dolazilo do antirežimskih istupanja, kritikovanja vladajuće partije i njenih mera, političkog i društveno-ekonomskog sistema i do "reakcionarnih" i „ibeovskih“ provokacija i incidenata. Ni sama Partija, uprkos višegodišnjem

4 D. Bondžić, Beogradski univerzitet 1944-1952, 306-311; Момчило Митровић,

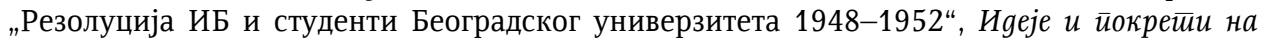
Беоіраяском универзитетеиу оg оснивања gо gанас, II, ур. Мирољуб Васић и др., (Београд: Центар за марксизам универзитета, 1989), 245-253.

${ }^{5}$ Više u: Srđan Cvetković, Između srpa i čekića III (Beograd: ISI, 2012). 
ideološko-političkom delovanju i stalnom nadzoru i pritisku, nije bila zadovoljna političkim stanjem na univerzitetima. ${ }^{6} \mathrm{U}$ duhu liberalnih promena $\mathrm{u}$ društvu i studenti su se osećali slobodnije, a njima svojstven društveni i politički radikalizam vremenom se ispoljavao u prvim protestima, demonstracijama i štrajkovima.

Najveći incident na početku tog perioda izbio je oktobra 1951. kada su studenti Građevinskog fakulteta Dragoš Jurišić i Sofronije Builo, inače obojica iz "reakcionarnih porodica", istupili na studentskom skupu protiv novih privrednih mera koje su smanjivale studentske privilegije i beneficije i izazvale pravu dramu među siromašnijim studentima. Javno suđenje krajem februara 1952. pretvorilo se u demonstracije protiv vlasti, a prilikom intervencije pripadnika UDB-e u civilu došlo je do opšte tuče. Optužene Buila i Jurišića disciplinski sud je marta 1952. udaljio sa Beogradskog univerziteta, ali oni nisu krivično gonjeni, što je bila posledica političke odluke da se instrumenti represije racionalnije upotrebljavaju nego u tzv. administrativnom periodu razvoja. List Narodni student je ovaj slučaj nazvao „mutivode na Gradevinskom fakultetu", a to je bila samo jedna od niza reakcija beogradskih studenata na ekonomske mere početkom 50 -ih godina. ${ }^{7}$

Tokom prve polovine 50 -ih godina došlo je $u$ dva navrata do bojkota predavanja na pojedinim fakultetima. Krajem novembra 1953. studenti Prirodno-matematičkog fakulteta (PMF) tražili su izmenu nastavnih planova, pravila studiranja i uvođenje slobodnog roka i njihovi zahtevi su brzo usvojeni. Do bojkota nastave iz sličnih razloga došlo je oktobra 1954. na Stomatološkom fakultetu, ali ovaj put zahtevi nisu usvojeni. Pošto se radilo o školskim pitanjima ovi incidenti nisu sankcionisani, ali su uznemirili partijsko rukovodstvo koje je insistiralo da se sva studentska pitanja rešavaju isključivo u okviru partijske i studentske organizacije. ${ }^{8}$ Može se reći da su početkom 50-ih godina sve „negativne pojave“ i nezadovoljstvo studenata na Univerzitetu uglavnom bili pod kontrolom, nisu bili organizovani i nisu pretili da pređu u masovne antirežimske nemire. ${ }^{9}$

${ }^{6}$ AJ, CK SKJ, 507, VIII, I-1/41 (k-1); AJ, 837, KPR, II-1/87, Zapisnik sa savetovanja po pitanju Univerztiteta, 16. 1. 1952; Pregled o obilasku partijske organizacije univerziteta i velikih škola u Beogradu, Zagrebu i Ljubljani, 12. 2. 1952; Д. Бонџић Универзииеии у соиијализму, 414-416.

7 Arhiv Srbije (AS), fond Beogradski univerzitet (BU), f. 139, Zapisnici i presude

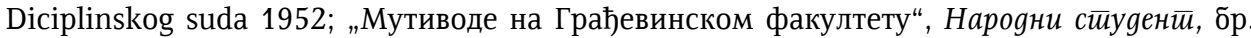
28, 7. 12. 1951, 3; Предраг Ј. Марковић, Беоі̄pag између Исйока и Зайаga 1945-1965 (Београд, Службени лист СРЈ, 1996), 188-189; Д. Бонџић, Универзииеей у соиијализму, 413414; Svedočenje arhitekte Predraga Ristića iz Beograda, dato S. Cvetkoviću septembra 2004.

8 Д. Бонџић Универзииетеи у соиијализму, 427-428.

${ }^{9}$ Predrag J. Marković, „Najava bure: studentski nemiri u svetu i Jugoslaviji od Drugog svetskog rata do početka šesdesetih godina", Tokovi istorije, br. 3-4 (2000), 57-58. 
Prema istraživanjima Đorđa Stankovića, prvi studentski štrajk se desio u Studentskom gradu na Novom Beogradu 29. oktobra 1953. i potpuno zbunio studentske funkcionere navikle da takve manifestacije organizuju vlasti. Mada je Beogradski univerzitet bio preopterećen i predstavljao problem za platežne mogućnosti Beograda i Srbije, studenti su smatrali da smeštaj i hrana moraju biti jeftiniji i kvalitetniji. Nezadovoljstvo u Studentskom gradu kao najvećem studentskom naselju na Balkanu tinjalo je tokom 1953. godine. Celo naselje je noću neretko često zviždalo i protestovalo, a česti su bili okršaji sa policajcima u krugu Studentskog grada. Neredi su počeli posle informacije na razglasu da su povećane cene smeštaja i ishrane, kao i da je servirana pokvarena hrana. Nezadovoljni socijalnom situacijom i povećanjem cena stanarine i hrane u domovima i menzama, oko hiljadu studenata iz Studentskog grada je 29. oktobra 1954. pokušalo da prodre u grad i izrazi nezadovoljstvo, ali su ih kod nadvožnjaka presrele jake snage Narodne milicije, (konjičke brigade iz Zemuna i sa Banovog brda). Demonstranti su uzvikivali parole (Dole vlada i sl.) i gađali kamenjem milicionere koji su ih presreli. Policija je upotrebila brutalnu silu hapseći u velikom broju svakog ko bi se našao u okolini Studentskog grada. ${ }^{10}$ Okupljanje ispred Filozofskog fakulteta i PMF-a je sprečeno. Postoje podaci o upotrebi sile i policijske torture prema uhapšenima, ali je direktiva sa vrha (verovatno Veljka Vlahovića ili Aleksandra Rankovića) bila da se uhapšeni studenti ne osuđuju na duže kazne zatvora već da se stvari raščiste na fakultetima, političkim i disciplinskim putem. Iz Saveza komunista Jugoslavije (SKJ) isključeno je oko 40 članova i kažnjeno oko 130, iako su neke partijske organizacije odbile da osude svoje članove, kao PMF i Šumarski fakultet. Samo su retki od kolovođa protesta osuđeni (Branko Gudalo, student tehnologije iz Beograda, osuđen je pred Okružnim sudom Beograda na 7 meseci zatvora). Većim delom studenti su kažnjavani pred disciplinskim sudovima (udaljavanjem sa fakulteta, zabranom polaganja ispita u određenom roku itd.). Uhapšene je saslušavala milicija, ali i revnosni aktivisti sa Univerziteta. Tokom isleđivanja neki su tučeni i maltretirani, a od njih je zahtevano da otkriju pozadinu i pokretače nemira („strane podstrekače“, „domaće podstrekače“, „đilasovce“, "ibeovce“, "ostatke reakcionarne buržoazije“ itd.). Protest je potpuno prećutan u javnosti, kako se ne bi kvarila optimistička slika razvoja socijalističkog društva. Novine su ćutale o ovom događaju, dok je Njujork tajms objavio dosta detaljnu vest 16. novembra 1953 (Beograd brani studentske nerede) napominjući da su se prvi put čule i parole protiv vlade. Policija je sumnjala da iza protesta stoje đilasovci, ibeovci ili drugi „narodni neprijatelji“,

10 „Zabarikadirani u spavaonicu, gadali su miliciju ugljem i cepanicama. Posle trodnevne opsade štrajk je slomljen. Mnogi su se našli iza rešetaka“, Živojin Pavlović, Ispljuvak pun krvi (Novi Sad: Prometej, 1999), 18. 
ali o tome nije imala nikakvih dokaza. Istraživači ovog perioda uglavnom se slažu da je protest imao socijalne motive i da nema dokaza o političkoj instrumentalizaciji, niti umešanosti inostranog faktora. Partijski organi su uzrok nemira nalazili u pasivnosti komunista i slabom ideološko-političkom radu. ${ }^{11}$

Osim ovih demonstracija, tokom 50 -ih i početkom 60 -ih godina među beogradskim studentima nije bilo obimnog i organizovanog otpora režimu. Studenti su bili učesnici organizovanih režimskih manifestacija i demonstracija sa spoljnopolitičkim i drugim povodima (pitanje Trsta 1953, protest zbog ubistva Patrisa Lumumbe 1961, izbori, proslave, itd.) na kojima je povremeno dolazilo do neželjenih ispada. Nekoliko incidenata među studentima Beogradskog univerziteta zabeleženo je u vreme pada Milovana Đilasa s vlasti: uoči plenuma na kome će biti smenjen, neke grupe studenata dočekale su Đilasa aplauzima; iste godine na Filozofskom fakultetu studenti su organizovali „spontan“ bojkot predavanja Dušana Nedeljkovića, koji je dve godine ranije izbačen iz Partije; novembra 1954. studenti Filozofskog fakulteta su bojkotom sprečili Vladimira Dedijera, koji je podržao Đilasa, da održi prvo predavanje na predmetu Istorija narodne revolucije. Do kraja decenije bilo je pojedinačnih slučajeva kažnjavanja studenata zbog verbalnih istupa, kritika narodne vlasti, pričanja viceva, itd. Maja 1959. došlo je do manjeg incidenta u menzi Tri kostura jer su studenti bili nezadovoljni hranom. ${ }^{12}$ Istovremeno, sve su bili veći problemi sa studentima $u$ Studentskom gradu (Novi Beograd) gde je zabeležen povećan broj napada na organe reda pa neki istraživači tu vide korene „1968“. Smatra se da je osnovni i prikriven uzrok sukoba bilo nezadovoljstvo naroda ekonomskom situacijom u zemlji. S druge strane, uzrok nemira se traži i u opštem nezadovoljstvu i levom radikalizmu mladih, sa socijalnim i političkim konotacijama u vreme zaoštravanja sukoba KPJ i sa Istokom i sa Zapadom. ${ }^{13}$

${ }^{11}$ Đorđe Stanković, „Pobuna gladnih među gladnima“, Borba, br. 156, 5. jun 1991 , 16; Isti, „Strana propaganda u postocima“, Borba, br. 157, 6. jun 1991, 12; Исти, „Побуна гладних међу гладнима - студентске демонстрације у Београду 1954. године“, Изазов нове истиорије, 1 (Београд: Војноиздавачки и новински центар, 1992), 188-201; Исти,

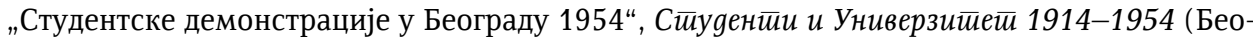
град: Центар за савремену историју Југоисточне Европе, 2000), 223-248; Д. Бонџић Универзитеиеи у сои,ијализму, 428-429.

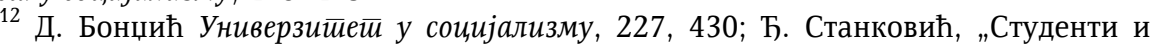
универзитет“, 223-248; П. Марковић, Беоіраg између Исйока и Зайаgа, 191; Ђорђе Станковић и Љубодраг Димић, Исйориоірафија йоg наgзором, 1 (Београд: Службени лист CPJ, 1996, 211-212; P. Marković, „Najava bure“, 59. Do većih demonstracija 11. maja 1959. došlo je u Zagrebu, Rijeci i Skoplju (Zdenko Radelić, Hrvatska u Jugoslaviji 1945-1991 - od zajedništva do razlaza (Zagreb: Hrvatski institut za povijest, 2006), 329, 343, 352; Dragomir Bondžić, „Pisanje jugoslavenske i strane štampe o studentskim demonstracijama u Zagrebu i Skopju u svibnju 1959“, Historijski zbornik, br. 2, (2011), 499-514).

13 Алекс Драгнић, Тишиова обећана земља Јуіославија (Београд: Чигоја штампа, 2004), 166, 392; П. Марковић, Беоі̄pag између Исйока и Зайаgа, 191-193. 


\section{Jačanje otpora 60-ih godina}

Nakon relativne liberalizacije $\mathrm{u}$ vreme samoupravnog socijalizma otpor zamire naročito tokom perioda 1956-1966. godine. Širi front studentskog otpora i kritike u zemlji zapaža se tek od druge polovine 60-ih, kada stasavaju mlađi i obrazovaniji kadrovi školovani i odrasli posle rata. Oni koriste relativnu liberalizaciju režima, pre svega u sferi kulture i medija, za kritičko sagledavanje društvene stvarnosti i prve javne manifestacije nezadovoljstva (demonstracije, štrajkovi i dr.). Novi centri otpora postaju legalne i ilegalne studentske organizacije, klubovi književnika, pojedine kulturne i naučne institucije. Menja se i ideološki osnov otpora. Kritika i otpor dolaze sada sve više sa pozicija levice ili bar uvijene u marksistički diskurs, a intenzitet delovanja je sve izraženiji uoči studentskih demonstracija u Beogradu 1968. godine. Ideološki, većina studentskih lidera je zadojena idejama filozofa nove "levice". Studenti su pod uticajem teza Herberta Markuzea da je radnička klasa u kapitalizmu i šire prevaziđena kao noseći subjekt revolucionarne akcije i da ne "poseduje potrebnu političku klasnu svest budući suviše integrisana u sistem". Revolucionarna delatnost, po Markuzeu, pada na leđa studenata i inteligencije; oni se nisu sasvim integrisali i poseduju političku svest - „revolucionarni subjekt za sebe“, koje treba da posluže kao katalizator šireg društvenog bunta i radničke klase - „revolucionarni subjekt po sebi“ ${ }^{14} \mathrm{U}$ duhu vremena mogle su se čuti razne „uvezene parole" pacifizma, razoružanja, borbe protiv potrošačkog društva, demokratizacije društva i Univerziteta itd. Generacijski posmatrano, radilo se o mladim ljudima koji su stasali posle rata i koji imaju potrebu da kritički preispituju društvene procese. To je i opšti fenomen pobune prekobrojne baby bum generacije koja dolazi na fakultete, uz druge kulturološke faktore: uticaj masovne kulture, rokenrola itd. Kao i u drugim zemljama i ovde su nemiri počeli $u$ vidu socijalnih zahteva, sukobom studenata i univerzitetske vlasti, pa su prerasli u širi sukob dela inteligencije i ideološko-političkog aparata, oko slobode stvaralaštva i političkih sloboda.

U UDB-i je 60-ih godina primećeno da "Dosadašnji sastav studenata, njihova individualnost i grupna štetočinska istupanja i sve ono što se svakodnevno zbiva u njihovoj sredini nameće potrebu za jednim novim kursom obrade studenata $i$ svih pojava vezanih za njih". ${ }^{15} \mathrm{U}$ to vreme neki od studenata bili

${ }^{14}$ Markuze primećuje kako evropski studenti žive u takvim uslovima koje ne bi prihvatio nijedan američki radnik i da su oni središnji element u budućoj proizvodnji. AJ, CK SKJ; Ideološka komisija VII, II /8 (1-84), Informacija s Pete sesije Korčulanske letnje škole, 14-24. avgust 1968, Izlaganje H. Markuzea, 35.

15 AJ, Vrhovni sud Jugoslavije, 212-18, Izveštaj o deformacijama u radu Službe državne bezbednosti oktobar 1966, 14. 
su i članovi brojnih ilegalnih omladinskih „reakcionarnih“, „kontrarevolucionarnih" ili „nacionalističkih" organizacija, koje je otkrivala tajna policija. ${ }^{16}$ Od druge polovine 60 -ih beogradski studenti raznim povodima izlaze na ulice i demonstriraju.

Tokom decembra 1966. organizovane su studentske demonstracije $u$ Sarajevu, Zagrebu i Beogradu, a povod je bio podrška narodu Vijetnama. Demonstracije uz podršku vlasti su zakazane za 23. decembar 1966, a prisustvovalo je oko 3.000 demonstranta mahom studenata. Među učesnicima bio je i Ivo Andrić, a među govornicima Dobrica Ćosić i Dragoljub Mićunović. Uzvikivale su se parole Živeo narod Vijetnama, potpisana je peticija koja je trebalo da bude uručena Ambasadi SAD. Pokušaj je, međutim, sprečila vlast - protiv demonstranata je intervenisala milicija. Studenti su krenuli da telima probijaju kordon ali je milicija upotrebila šmrkove, suzavac i palice. Goneći studente milicija je prodrla čak na Filozofski fakultet gde je jurila studente po učionicama i kabinetima. Grupa od dvadesetak demonstranata koja se probila do američke ambasade u ulici Kneza Miloša uhapšena je i osuđena na mesec dana zatvora zbog remećenja javnog reda i mira, "bacanja snega na milicionare i građane", „ulične galame“. Demonstracije u Beogradu dovele su do partijske istrage sa oštrim sporovima partijskih rukovodilaca sa Univerziteta, naročito na odeljenjima za sociologiju i filosofiju. Partijske kazne su izrečene A. Kronu, J. Ferlugi i A. Hodžiću za raspirivanje dalje politizacije studenata i profesora. ${ }^{17}$

U proleće 1968. najavljene su demonstracije povodom posete komandanta Šeste flote SAD Dubrovniku (6. aprila 1968), a održane su i pred otpravništvom SR Nemačke povodom donošenja Zakona o vanrednom stanju uperenom protiv studentske levice (11. maja 1968). Studenti Filozofskog fakulteta protestovali su i aprila 1968. protiv nasilja prema studentima u

${ }^{16}$ Milo Bošković, Antijugoslovenska fašistička emigracija (Novi Sad: Sloboda, 1980), 256-257; AJ, SIV, 130-558, Izveštaj o radu SSUP-a za 1964. godinu; AJ, fond Vrhovni sud Jugoslavije, 212-18, Izveštaj o deformacijama u radu Službe državne bezbednosti, 9; AJ, SIV 130-558, Odeljenje za upravne poslove SSUP, Godišnji izveštaj za 1968, 30. april 1969, 19; AJ, SIV, 130-558, Analiza osposobljenosti i efikasnosti organa unutrašnjih poslova, SSUP mart 1970, 79; Bojan Dimitrijević, „Odjek Brionskog plenuma na Službu unutrašnjih poslova 1966-1970“, Istorija 20. veka, br. 2 (2001), 75-85.

${ }^{17}$ Nebojša Popov, Društveni sukobi - izazov sociologiji. Beogradski jun 1968 (Beograd: Službeni glasnik, 2008), 162; M. Petrović, „Kotrljanje glave od kaldrme do asfalta“, Njusvik, br. 67, 30. 5. 2016. Videti više u: Radina Vučetić, „Violence against the antiwar demonstrations of 1965-1968 in Yugoslavia: political balancing between East and West", European History Quarterly, vol. 45, no. 2 (April 2015), 255-27; James Mark, Peter Apor, Radina Vučetić, and Piotr Oseka, „'We are with you Vietnam': Transnational Solidarities in Socialist Hungary, Poland and Yugoslavia“, Journal of Contemporary History, vol. 50, no. 3 (2015), 455-456. 
Poljskoj. Tome se usprotivio Univerzitetski odbor, zbog toga što je akcija sprovedena bez odobrenja višeg foruma. ${ }^{18}$

\section{Prekretnica: junske studentske demonstracije u Beogradu 1968. i odjeci $^{19}$}

Najmasovnija studentska pobuna u SFRJ posle Drugog svetskog rata bila je ograničena na Beograd i tek je delom zahvatila Sarajevo, Zagreb i Ljubljanu. Delimično je podstaknuta nizom demonstracija koje su od 1966. zahvatile sve veće univerzitetske centre u svetu (protesti u SAD, Zapadnoj Evropi i Čehoslovačkoj - Praško proleće). Ostaju da se istraže i unutrašnji faktori: kampanja liberalizacije posle pada Rankovića, narasle društvene nejednakosti koje su postajale sve uočljivije zbog parcijalnog uvođenja tržišnih mehanizama privrednom reformom 1965, kao i drugi društveni faktori od uticaja. Kritika društva s pozicija neostvarenih ciljeva i ideala, parole egalitarizma, protiv crvene buržoazije bili su glavni idejni tokovi šezdesetosmaša.

Povod za junske demonstracije u Beogradu bio je sukob do kojeg je došlo 2. juna 1968. između studenata iz Studentskog grada na Novom Beogradu i brigadista radne akcije Novi Beograd 1968. oko ulaza u salu Radničkog univerziteta na priredbu Karavan prijateljstva. U obračun se umešala policija, pri čemu je više studenata, brigadista i milicionara povređeno. Tokom noći okupljena masa od oko 3.000 studenata demonstrira, govornici traže odgovornost za nasilje i stanje $u$ društvu, a jedna grupa je polupala prozore $\mathrm{u}$ brigadirskom naselju. Kolona studenata i građana odlučuje da krene prema Beogradu, gurajući pred sobom vatrogasna kola zaplenjena

${ }^{18}$ N. Popov, Društveni sukobi, 162; Dragomir Bondžić, „Protesty studentow w Polsce w marcu 1968 roku - perspektywa jugoslowianska“, in: Polska i Jugoslawia po II wojnie swiatowej, pod redakcja Momčilo Pavlovicia, Nebojšy Stamboliji, Andrzeja Zaćminskiego, (Bydgoszcz: Instytut Historii i Stosunkow Miedzynarodowych UKW, 2016), 209-210.

${ }^{19} \mathrm{O}$ studentskim demonstracijama 1968. i studentskom pokretu u SFRJ uopšte postoji znatna literatura, sociološka i istorijska. Na 40-godišnjicu demonstracija izašlo je više publikacija, održano više naučnih skupova i objavljen zbornik radova 1968 - četrdeset godina kasnije, ur. Radmila Radić (Beograd: INIS, 1968). Videti i: Dragan Marković i Savo Kržavac, Liberalizam od Đilasa do danas, Pokušaj likvidacije SKJ i nova levica (Beograd: Sloboda, 1978); N. Popov, Društveni sukobi...; Isti, Contra fatum slučaj grupe profesora Filozofskog fakulteta u Beogradu 1968-1988 (Beograd: Mladost, 1990); Мирко Арсић и Драган Марковић, '68,

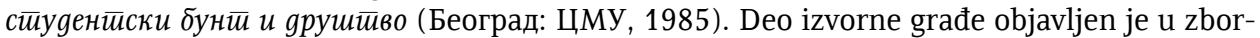
nicima Dokumenti (jun-lipanj) 1968 (Zagreb: Praxis, 1971); Študentsko gibanje 1968-1972, priredili Ciril Bašković, et al. (Ljubljana: RK ZSMS, 1982); Beogradski univerzitet i '68. Zbornik dokumenata o studentskim demonstracijama, prir. Momčilo Mitrović i Dobrica Vulović (Beograd: CMU, 1989); Šezdeset osma - lične istorije, prir. Đorđe Malavrazić (Beograd: RTS, Službeni glasnik, 2008); itd. 
tokom sukoba. Kod Podvožnjaka ih zaustavlja kordon milicionera. Prilikom pregovora dolazi do koškanja, odjeknuli su i pucnji, pogođen je jedan student, da bi ubrzo usledio brutalan obračun milicije sa okupljenim studentima, uz upotrebu palica i vatrenog oružja. Tanjug i zvanična štampa za sukob okrivljuju „razjarene studente“, dok Akcioni odbor demonstracija preko razglasa u Studentskom gradu poziva na novi protestni miting protiv nasilja nad studentima. Mitingu su osim studenata prisustvovali prorektor Univerziteta, profesori Lj. Tadić, D. Mićunović, S. Stojanović, političar Veljko Vlahović itd. Nose se parole Studenti - radnici, Tito - partija, ali i Hoćemo posao, Dole socijalistička buržoazija, Pucali su u nas, Ja sam prebijen, Mi smo sinovi radnog naroda, Dole šef ubica - Bugarčić, Sloboda štampe i demonstracija!. Prilikom pokušaja da ponovo krenu ka centru grada studenti su opet zaustavljeni kod Podvožnjaka, a tokom pregovora koje je, između ostalih, vodio student Vladimir Mijanović (Vlada Revolucija) izbija sukob. Policija kreće u napad prebijajući sve redom. Povređeno je više stotina studenata i građana. Prema pisanju Studenta radilo se o 134 povređena studenta, 9 brigadista, 5 građana i 21 milicioner. ${ }^{20}$ Bilans demonstracija bio je na desetine razbijenih prozora, ispaljenih revolverskih metaka, spaljena vatrogasna cisterna, upotrebljeno nekoliko hiljada gumenih palica i na desetine suzavaca. ${ }^{21}$ Posle višednevnih sukoba, demonstracija, protesta, danonoćnog zborovanja, blokade fakulteta, uz podršku i nastupe javnih ličnosti i umetnika, stotina parola, postavljanja zahteva, diskusija, zasedanja partijskih plenuma, hapšenja studenata - studentske demonstracije u Beogradu su završene 9. juna, posle obraćanja Josipa Broza Tita u kojem je podržao zahteve studenata i obećao rešavanje brojnih društvenih problema koji su pokrenuti.

Najveći intenzitet studentski protesti 1968. dostigli su u Beogradu, dok su u Zagrebu, Sarajevu, Ljubljani, Novom Sadu i drugim univerzitetskim centrima bili samo odjeci. Zahtevi protesta, za razliku od kasnijih demonstracija na Kosovu i Makedoniji i u Hrvatskoj, ticali su se demokratizacije političkog života, borbe za socijalne reforme, protiv društvene nejednakosti, borbe protiv birokratije i specifičnih problema školovanja i studiranja. Nebojša Popov uočava privremenu koaliciju liberala i konzervativnih komunista u obračunu sa studentskim pokretom, što je po njemu bila predigra za glavni sukob koji se desio između njih nekoliko godina kasnije. ${ }^{22}$

Krajem novembra 1968. izbile su demonstracije Albanaca na Kosovu i u Makedoniji sa hiljadama učesnika, mahom mlađih ljudi i studenata. Za

${ }^{20}$ Student, 4. 6. 1968, 1. vanredni broj; Ž. Pavlović, Ispljuvak pun krvi, Dnevnik 68, 20-21, 27.

${ }^{21}$ Student, 11. 6. 1968.

${ }^{22}$ N. Popov, Društveni sukobi, 211-220. 
razliku od većine studentskih skupova tokom juna 1968. zahtevi su gotovo $\mathrm{u}$ potpunosti bili okrenuti nacionalnim ciljevima - za veću samostalnost Kosova (Kosovo republika!) ili potpunu samostalnost. Demonstranti u Prištini, njih nekoliko hiljada, najpre su se okupili pred zgradom Filozofskog fakulteta i krenuli prema centru, zgradama Pokrajinskog komiteta, Skupštine i pokrajinskog SUP-a. Tražili su puštanje zatvorenih demonstranata i tom prilikom je došlo do okršaja sa policijom. Mogle su se čuti i videti parole: „Tražimo samoopredeljenje“, "Tražimo republiku“, „Dole kolonijalistička politika prema Kosmetu“, "Živeo Tito - Živeo Fadilj“, „Hoćemo da Kadri Halimi bude naš predsednik“ (tek što je izašao sa robije), „Živeo Adem Demaći““ (još u zatvoru), "Minut ćutanja za Grajčevci Fazlija“ (umro u zatvoru 1964) itd. Tenkovska divizija JNA iz Skoplja dobila je naređenje da krene prema prelazu Đeneral Janković kroz Prištinu prema kasarni u Vučitrnu. Na Kosovo je poslato dodatnih 4.000 policajaca iz Srbije. U toku demonstracija povređeno je 10 pripadnika milicije, 4 vatrogasca i 27 građana koji su zatražili lekarsku pomoć ( 8 zadržano u bolnici). Demonstranti su razbijali izloge, napadali organe reda i objekte. Slično kao i u Beogradu, policija i vojska su zaposele objekte i dobile nalog da pucaju ako se napadnu ključne institucije (Skupština, TV, radio itd.). Jedan učesnik u demonstracijama je poginuo (Slavko Zečević tvrdi da je, navodno, ubijen od samih demonstranata). Istog dana izbijaju demonstracije u Gnjilanu, Podujevu, Peći i Uroševcu, gde je, pored materijalne štete, lakše povređeno i 7 radnika SUP-a. Posle demonstracija u Prištini i drugim mestima na Kosovu pokrenut je postupak protiv 20 lica, među kojima 10 studenata i 3 učitelja, a prekršajno su kažnjena 53 učesnika u izgredima. Prilikom sudskog procesuiranja oslobođeno je na desetine lica, protiv kojih je pokrenut administrativni postupak (najviše onih iz Peći). ${ }^{23}$

Beogradski studenti se nisu smirili ni posle 1968. Na vest da su rudari Kaknja stupili u štrajk 20. juna 1970. desetak studenata Beogradskog univerziteta zaposelo je učionicu Filozofskog fakulteta i proglasilo štrajk glađu. Pridružio im se glumac Zoran Radmilović u znak solidarnosti sa "gladnim rudarima Kaknja i ostalim gladnim ljudima u Jugoslaviji“. Glavni zahtev je bio socijalne prirode: da SIV garantuje iz sredstava federacije barem jedan

${ }^{23}$ Podnete su krivične prijave protiv 87 lica, najviše iz Tetova, Gostivara i Skoplja. U Tetovu je otkrivena ilegalna nacionalistička organizacija. Organizacije na Kosovu i Makedoniji oslanjale su se na bivše političke osuđenike, studente, prosvetni kadar i pojedine hodže koje su imale veliki uticaj u narodu. AJ, SIV, 130-559, SSUP, Informacija povodom demonstracija na SAP Kosovu i SR Makedoniji, 31. januar 1969, 6, 10-11; Neprijateljske demonstracije u Prištini, Uroševcu, Gnjilanu i Podujevu u: Pero Simić, Zvonimir Despot, Tito, strogo poverljivo, Beograd 2010, 260-264; Slavko Zečević, Sećanja i kazivanja, (Beograd: Publikum, 2004), 260-261; Predrag. J. Marković, „Služba državne bezbednosti i albanske demonstracije na Kosovu 1968. godine: jedan dokument", Istorija 20. veka, br. 1/2 (1999), 169-180. 
mesni obrok nedeljno i slično. Tokom štrajka narušena je autonomija Univerziteta, jer su organi bezbednosti vršili nenajavljen pretres prostorija ne dozvoljavajući dekanu Nikoli Rotu da izađe iz kancelarije. Štrajk studenata okončan je 26. juna 1970. kada su rudari obustavili štrajk, pošto su im zahtevi ispunjeni. Štrajk je bio jedan od povoda za prvu osudu Vlade Mijanovića Revolucije, jednog od lidera šezdesetosmaša. Veći broj studenata je podvrgnut administrativnim kaznama i oduzimanju pasoša, dok je u proleće 1970. student Božidar Borjan osuđen na mesec dana zatvora zbog uređivanja interne publikacije studenata filosofije, časopisa Krug. ${ }^{24}$

Štrajk podrške Vladi Revoluciji oktobra 1970. bio je čin demonstriranja podrške optuženom $u$ vreme političkog procesa. To predstavlja retkost $u$ socijalističkoj, naročito staljinističkoj društvenoj praksi gde su demonstracije po pravilu uperene protiv optuženog i organizovane od strane vlasti. Ovo je prvi poznat takav slučaj posle 1945, za razliku od 80-ih kada javni protesti i peticije za oslobađanje optuženih u vreme suđenja postaju gotovo pravilo. Početak štrajka proglasio je zbor studenata Filozofskog fakulteta (uz prisustvo oko 700 studenata) 21. oktobra 1970. „u znak protesta protiv političkog procesa Vladi Mijanoviću i podrške štrajku glađu u koji je stupio“, kada je izabran i štrajkački Akcioni odbor. Tokom procesa demonstrirala je grupa studenata Filozofskog i Filološkog fakulteta. Protest nije podržan od profesora i zahvatio je samo dva fakulteta (Filozofski i Filološki) i dve umetničke akademije (Dramska i Likovna). Bila je planirana diverzija i protestni skup u vreme Korčulanske letnje škole što su sprečile lokalne vlasti. Protestnu peticiju potpisali su intelektualci: E. Bloh, Ž. P. Sartr, N. Čomski, L. Goldman i drugi. ${ }^{25}$ Protest je ostao bez masovnije društvene podrške, a izolacija štrajkača u javnosti bila je potpuna. Izuzetak su afirmativni članci K. Čavoškog i A. Stojanovića u Studentu, gde se ističe da proces podseća na minulu epohu naše revolucije. ${ }^{26} \mathrm{U}$ medijskoj diskreditaciji štrajka najdalje su otišle Večernje novosti koje su pisale da je među štrajkačima pronađen pravi psihijatrijski slučaj, „individuum" duševno oboleo, pod naslovom Psihijatri traže lažnog studentskog lidera („Ante Rumora slepi putnik u karavanu prijateljstva nije ni student, ni funkcioner zagrebačke studentske organizacije, već mlad čovek kome je potreban nastavak lečenja). “27 Štrajk je neuspešno okončan posle deset dana pozivom Mijanoviću da prekine štrajk glađu i porukom da će Savez ubrzo prerasti u pokret s ciljem stvaranja

${ }^{24}$ N. Popov, Društveni sukobi.

25 Tokom protesta na sednici Saveta Univerziteta 26. oktobra 1970. mogao se čak čuti radikalan stav da Filozofski fakultet treba isključiti sa Univerziteta, koji su zastupali dekani Saobraćajnog i Rudarsko-geološkog fakulteta. N. Popov, Društveni sukobi, 195-196.

${ }^{26}$ Student, 3. 11. 1970; Student, 17. 11. 1970.

27 Tu ličnost policija je uhapsila dok se sa dvojicom kolega kretao od Akademije za pozorište, film i radio ka Filozofskom fakultetu. N. Popov, Društveni sukobi, 197. 
"delatnog Saveza studenata Beograda, demokratske i samostalne organizacije“. Međutim ne samo da nije prerastao u tako nešto, već je ubrzo 1974. nestao kao takva politička organizacija. ${ }^{28}$

\section{„Crni talas“ - intenziviranje represije 1972-1981}

Početkom sedamdesetih godina posle studentskih demonstracija 1968, likvidiranja Maspoka u Hrvatskoj i obračuna sa srpskim liberalnim rukovodstvom, država je brutalnom represijom ugušila vrenje na univerzitetima i među studentskom omladinom. Posle čestih i masovnih protesta $\mathrm{u}$ vremenu 1966-1972, usled intenziviranja političke represije i zavođenja čvrste ruke dolazi do oseke javnih protestnih okupljanja, posebno u Srbiji i Hrvatskoj. ${ }^{29}$ Partija je preko državnih institucija, sudova, policije i tužilaštva počela veliko čišćenje negativnih pojava, političkih neistomišljenika i raznih neprijatelja samoupravnog socijalizma. Buntovni pojedinci i mnogi pripadnici nezavisnih studentskih organizacija bili su sve češće na optuženičkoj klupi. Omladinske grupe su često optuživane da su vođene spolja ili pod direktnim uticajem političke emigracije. Takvo je bilo suđenje „trockistima“ (Inicijalna grupa za revolucionarnu radničku partiju - IGRRP). Okružni sud u Beogradu pokrenuo je početkom 1972. postupak protiv troje studenata Univerziteta u Beogradu, šezdesetosmaša: Milana Nikolića i Jelke Kljajić, studenata sociologije Filozofskog fakulteta i Pavluška Imširovića, studenta Saobraćajnog fakulteta. Uhapšeni su januara 1972. ${ }^{30}$

Vlast je bila naročito osetljiva na "horizontalno" povezivanje disidenata i studenata, stoga je brzo reagovala u slučaju pokušaja povezivanja nezavisnih studentskih organizacija. Tako su predstavnici tri fakulteta (Beograd-Zagreb-Ljubljana) održali sastanak 30. januara 1974. u Ljubljani i

${ }^{28}$ Isto, 198.

${ }^{29}$ Srđan Cvetković, Između srpa i čekića II (Beograd: Službeni glasnik, 2011), 353389. Tokom 1971. izbili su i studentski protesti u Ljubljani i Zagrebu. Dok su protesti u Ljubljani imali demokratske zahteve i sličnosti sa beogradskim iz 1968, protesti zagrebačkih sveučilištaraca od maja do decembra 1971. bili su povezani sa Maspokom i vođeni pre svega nacionalnim zahtevima i interesima. (N. Popov, Društveni sukobi, 201-202, 217-218; Z. Radelić, n. d., 442-457).

${ }^{30}$ Sekretar UK SK BU B. Pribićević je, samo dan po hapšenju, pored ostalog ustvrdio kako su uhapšena dva studenta za koje je već procenio da su vezana za „trockističku internacionalu“, a koja je, kao „ekstremna levica“ povezana sa neprijateljskim snagama u inostranstvu. Jelka Kljajić je inače sasvim slučajno priključena procesu jer se student J. Anđelković razboleo, pa je ona kao odličan student na Filozofskom fakultetu naknadno priključena grupi kako bi se popunio broj. P. Imširović i J. Kljajić, nakon što su osuđeni u navodnoj „grupi“, a da se nisu ni poznavali, zavoleli su se i po izlasku iz zatvora stupili u brak. Srđa Popović, Poslednja instanca I (Beograd: Helsinški odbor za ljudska prava u Srbiji, 2003), 51; N. Popov, Društveni sukobi, 172, Svedočenje Dragomira Olujića Oluje, Beograd 15. maj 2008. 
pokrenuli inicijativu za osnivanje Saveza studenata Filozofskih fakulteta Jugoslavije, koja bi usvojila Nacrt Rezolucije o prilikama u zemlji. U ovom nacrtu, koji odiše zaklinjanjem u socijalizam, samoupravljanje, marksizam i Program SKJ, na indirektan način se kritikuje režim sa pozicija levice i osuđuje politička represija usmerena na rušenje autonomije Univerziteta. Rezolucija je brzo sudski zabranjena, a neki autori osuđeni na kaznu zatvora (septembar 1974), dok je Savez studenata ukinut kao samostalna organizacija. ${ }^{31}$ Osuđeni su na po 10 meseci za krivično delo „neprijateljske propagande" i "udruživanja protiv države i društvenog uređenja", da bi im viša instanca po žalbi umanjila kaznu na 6 meseci, na čije izdržavanje nikad nisu ni otišli. ${ }^{32}$

U drugoj polovini 70-ih sve više se išlo na javno i poluilegalno delovanje, peticije, tribine a od početka 80 -ih na štrajkove, demonstracije i druge forme javnog izražavanja protesta i otpora. Njih takođe nose mlađi ljudi, ali one nemaju više karakter omladinskih i đačkih družina već se ova populacija sve više utapa $u$ širi demokratski front delovanja protiv nedemokratskog režima u predvečerje obnove višestranačja. Krajem 70 -ih i početkom 80 -ih $\mathrm{u}$ javnosti su organizovane mnoge peticije koje su potpisivali gotovo svi aktivisti borbe za građanska i politička prava u SFRJ - za ukidanje moralno-političke podobnosti kao uslova za zapošljavanje 1978; za uspostavljanje slobode štampe 1979; otvorena pisma podrške Povelji 77 u Čehoslovačkoj 1977, kao i pokretu Solidarnost 1981. u Poljskoj; za oslobađanje političkih osuđenika i brisanje člana $133 \mathrm{KZ}$, koji sankcioniše neprijateljsku propagandu 1980; itd. Peticije su upućivane državnim organima, medijima i inostranim organizacijama, mahom preporučenom poštom. Od 1976. disidenti u Beogradu pribegavaju i osnivanju neformalnih diskusionih grupa i tribina po privatnim stanovima - tzv. Slobodni univerzitet. Prvi organizatori su bili Vlada Mijanović, Lazar Stojanović, Dragomir Olujić i drugi. Ovaj vid

${ }^{31}$ Pred OKS u Ljubljani, u prvoj polovini 1974, uslovno su osuđeni studenti Vinko Zalarj i Darko Štrajn iz Ljubljane, zatim Lino Veljak i Mario Rubi sa Filozofskog fakulteta u Zagrebu i Zoran Đinđić i Miodrag Stojanović sa beogradskog Filozofskog fakulteta. Zoran Đinđić je tako još kao student, tri decenije pre nego što je postao predsednik Vlade i žrtva atentata u kojem su učestvovali delovi tajne službe, postao predmet obrade SDB i svrstan u red unutrašnjih neprijatelja „anarholiberala i maoista“: „Svedočenje Srđe Popovića“, TVdokument, Pravila službe, B 92, 5. oktobar 2008.

${ }^{32}$ Vladimir Palančanin je jedini koji je kaznu i odležao, dok je ostalima progledano „kroz prste", najverovatnije što se tada spremao udar na profesore praksisovce. Advokat S. Popović uočava još dve zanimljivosti na ovom procesu. Najpre, da je istinitost tvrdnji u Nacrtu rezolucije utvrđivana upoređivanjem sa partijskim rezolucijama, a ne stvarnim činjeničnim stanjem i, drugo, da identična kritika koja se iznosi u zvaničnom partijskom diskursu postaje kažnjiva ako je izgovori neko drugi. Služba bezbednosti je to nazivala „krađom tuđih leđa" a Partija „potrebom da se SKJ stavi na čelo kritike“; S. Popović, n. d., 555-572. Svedočenje Jove Vukelića autoru, Beograd 7. oktobar 2009. 
borbe organizovan je po modelu sličnih akcija koje su vođene u Čehoslovačkoj i Poljskoj - Letećeg univerziteta, a teme predavanja i diskusija su bile raznolike: od samoupravljanja, pravnog sistema, kulturnih i umetničkih sloboda, ekonomskih pitanja do nacionalnog pitanja i uređenja države. ${ }^{33}$

U periodu od 1972. do 1980. javni protesti su bili retki i svodili su se na izolovane pokušaje pojedinaca i grupa koji su sprečavani odlučnom akcijom organa reda (npr. pokušaj okupljanja i demonstracija prilikom održavanja sastanka KEBS-a u Beogradu maja 1977). ${ }^{34}$

\section{„Novi val“ - protesti osamdesetih}

Masovniji javni otpori i protesti zbog kršenja političkih i ljudskih prava ponovo su učestali tek posle Titove smrti kroz peticionaške akcije, tribine, osnivanje odbora za odbranu ljudskih prava i slobode misli, javne proteste i slične forme političkog aktivizma. Značajna stavka u pokretu bilo je pozivanje na međunarodne dokumente koje je država ratifikovala (Povelju OUN i Helsinšku povelju iz 1975). Ton inače napetoj društvenoj atmosferi posle smrti Josipa Broza Tita posebno su dale velike separatističke demonstracije Albanaca na Kosovu, u velikoj meri studenata i srednjoškolaca, koje su buknule tokom marta 1981. i bile zvanično ocenjene kao pokušaj „kontrarevolucije“. Kao antipod ovim demonstracijama na sahrani Aleksandra Rankovića avgusta 1983, koja se otrgla kontroli i prerasla u javni protest sa nacionalnim predznakom, okupilo se oko 100.000 ljudi. To je bila svojevrsna manifestacija tihog otpora i odgovora na albanske demonstracije i ustavne promene 70-ih koje su davale pokrajinama status „države u državi“ što je, kako se smatralo, doprinelo afirmaciji albanskog nacionalizma i separatizma. $^{35}$

Tokom 80-ih godina naglo se povećava broj mitinga podrške, književnih večeri, apela, peticija, protesta i javnih demonstracija protiv suđenja za

${ }^{33}$ Katarina Spehnjak, „Disidentstvo kao istraživačka tema - pojam i pristupi“, u: Disidentstvo u suvremenoj povijesti, ur. Nada Kisić Kolanović, Zdenko Radelić, Katarina Spehnjak (Zagreb: Hrvatski institut za povijest, 2010), 14; Vladimir Šeks, Delikt mišljenja (Osijek: V. Šeks, 1986), 177-186

${ }^{34}$ AJ, Predsedništvo SFRJ, 803-47, 80. sednica, maj 1977, Stenogrami sa sednice Predsedništva SFRJ, 36-43.

${ }^{35}$ AJ, Predsedništvo SFRJ, 68. sednica, 5. april 1981, Političko bezbednosna situacija u SAP Kosovo sa informacijom o sprovođenju donetih odluka Predsedništva SFRJ i SIV-a, stenogrami, 6; K. Spehnjak, Disidentstvo kao istraživačka tema, 282-284; Jasna Dragović Soso, Spasioci nacije. Intelektualna opozicija Srbije i oživljavanje nacionalizma (Beograd: Fabrika knjiga, 2004), 177-178; Vladimir Petrović, „Ekstremizacija jugoslovenskog političkog govora od smrti Josipa Broza do Osme sednice", u: S. Milošević - Put ka vlasti, Osma sednica CK SKS, ur. Momčilo Pavlović, Dejan Jović, Vladimir Petrović (Beograd: Institut za savremenu istoriju, 2009), 83. 
verbalni delikt i za zaštitu ljudskih i građanskih prava. To nisu bili masovni skupovi, ali su im težinu davali ugled pojedinaca i institucija koji ih organizuju. Predmet peticija postaju i odbrane političkih osuđenika kao neka vrsta javnog pritiska, a značajan prilog takvim akcijama daju odbori za odbranu slobode misli i izražavanja. Politički procesi doživljavaju neuspeh, optužena lica se oslobađaju ili im se umanjuje kazna u drugom stepenu (suđenje Goj$\mathrm{ku}$ Đogu tokom 1981, Vojislavu Šešelju 1984, Slobodnom univerzitetu 1985, Dragoljubu Petroviću 1986, itd.). Suđenja postaju kontraproduktivna jer sve više raspaljuju probuđenu javnost i kritički nastrojenu inteligenciju koja je, iako ideološki heterogena, bila ujedinjena u odbrani slobode javnog govora, štampe i diskusije kao temeljnih demokratskih vrednosti. Univerzitet (naročito Pravni i Filozofski fakultet), Srpska akademija nauka i umetnosti, pojedini instituti društvenih nauka, klubovi i udruženja književnika postaju epicentri slobodne misli i otpora. U javnosti se sve više istupa u prilog rehabilitaciji političkih osuđenika svih vrsta, od predratnih trockista, do žrtava poratnih montiranih procesa i ekskomunikacija 70 -ih godina. ${ }^{36}$

Organizuju se, uz to, mitinzi i peticije podrške demokratskim pokretima u svetu. Već krajem 1981. potpisuje se na Kolarčevom univerzitetu peticija protiv državnog udara koji je u Poljskoj izveo general Jaruzelski 13. decembra 1981. Tokom 9. jula 1982. zvaničnom mitingu solidarnosti sa Palestinskim frontom na Trgu Marksa i Engelsa u organizaciji Studentskog kulturnog centra (SKC) i Doma omladine, priključila se grupa koja je pružala podršku pokretu Solidarnost u Poljskoj. Brzo su uhapšeni i osuđeni pred Opštinskim sudom u Beogradu na 2 meseca zatvora zbog „povrede ugleda Jugoslavije“: Pavluško Imširović, Dragomir Olujić, Jovica Mihailović, Rada Karajović, Veselinka Zastavniković, Gordan Jovanović i Branka Katić. Student Miroslav Samardžić iz Zrenjanina organizovao je 16. jula 1983. protest zbog hapšenja grupe koja je podržala Solidarnost, ali su i oni pohapšeni (Ivan Janković, Vesna Pešić, Nebojša Popov, Boris Tadić, Milan Nikolić, Dragan Blagojević, Dušan Gamser). Svi su bili osuđeni od strane gradskog sudije za prekršaje na vremenske kazne od 25 do 40 dana koju su i odležali u Padinskoj skeli. Novinar Dušan Bogavac piše tekst protiv hapšenja za Politiku u večernjem izdanju, dok se u jutarnjem broju pruža podrška vlastima i hapšenju. Paradoks je bio da je Predsedništvo SFRJ samo šest meseci ranije na tajnom sastanku zauzelo stav da se Solidarnost u Poljskoj „bori protiv dogmatskih snaga i za socijalističku obnovu poljskog društva." ${ }^{37}$

${ }^{36}$ J. Dragović Soso, n. d., 82-105.

${ }^{37}$ Advokat Srđa Popović je zbog objavljivanja ove informacije priveden tokom noći na istražni razgovor, gde su službenici SDB pokušali da ga zastraše govoreći da se radi o dokumentu od najvećeg stepena tajnosti i da je učinio krivično delo objavljivanjem. S. Popović, Poslednja instanca, III, 1221-1226; Svedočenje Dragomira Olujića, Beograd 15. maja 2008; NIN, br. 1646, 18. jul 1982, 2 (pisma čitalaca); „Disidentska skrivalica“, Republika, br. 
Poslednji bunt studenata u ovom periodu bio je protest Hleb i so 1984. Studenti su protestujući protiv loše ishrane, poskupljenja i pogoršanja uslova života odbijali da jedu u menzama "uzimajući samo hleb i so" i izbegavajući otvoren sukob. Dolazilo je do neformalnog spontanog okupljanja ispred menze i na nekim fakultetima (Filozofski i Prirodnomatematički). Protest je pao u vreme tzv. Procesa šestorici slušalaca Otvorenog univerziteta pred Okružnim sudom u Beogradu kojima se sudilo za verbalni delikt, pa se spekulisalo da je s njim povezan. Potpuno je prećutan u javnosti i medijima, dok se o radničkim štrajkovima uveliko pisalo, što govori o većem strahu režima od studenata kao socijalne grupe. ${ }^{38}$

Sve „neprijateljske istupe“ u ovom vremenu uredno je zabeležila Bela knjiga (1984), koja je među beogradskim intelektualcima i disidentima pogrdno nazvana „manifestom staljinizma“. To je zapravo izveštaj Komisije CK Saveza komunista Hrvatske za idejni rad, sa Stipe Šuvarom na čelu, dosije neprihvatljivih poruka u kulturi i stvaralaštvu sa imenima više od 200 autora, većinom iz Srbije i Slovenije. Srpsko rukovodstvo, kako se smatralo, bilo je previše popustljivo prema beogradskoj kritičkoj inteligenciji i svojevrsnoj „ideološkoj kontrarevoluciji““. ${ }^{39}$ Kao vrsta samoodbrane od ovakvih akcija i represije vlasti nastao je 1984. Odbor za zaštitu slobode misli i izražavanja, kome su pripadali ideološki najrazličitiji pripadnici kritički nastrojenih intelektualaca. Odbor je tokom 80 -ih godina uputio niz pisama i peticija i poveo mnogobrojne akcije u odbrani slobode misli i izražavanja. Pre toga je već maja 1982. na inicijativu književnika Dragoslava Mihailovića u okviru Udruženja književnika osnovan Odbor za odbranu slobode umetničkog stvaralaštva (prvi članovi B. Mihajlović Mihiz, D. Maksimović, S. Raičković, R. Livada, P. Palavestra, B. Jovanović i drugi). ${ }^{40}$ Krajem 80 -ih pojavilo se

242-243, (2000), http://www.yurope. com/zines/ republika/arhiva/2000/242-243/242243_21.html

${ }^{38}$ Više u: N. Popov, Contra fatum.

${ }^{39}$ Bela knjiga 1984. Obračun sa „kulturnom revolucijom“ u SFRJ, prir. Srđan Cvetković, Kosta Nikolić i Đoko Tripković (Beograd: Službeni glasnik 2010); Katarina Spehnjak i Tihomir Cipek, „Disidenti, opozicija i otpor: Hrvatska i Jugoslavija, 1945-1990“, Časopis za suvremenu povijest, 2 (2007), 282; J. Dragović Soso, n. d., 102.

${ }^{40}$ Odbor za zaštitu slobode misli i izražavanja je imao najpre 19 članova pa je pridodato još četvoro. Članovi odbora koji je osnovao Dobrica Ćosić bili su: Borislav Mihajlović Mihiz, Dragoslav Mihailović, Dragoslav Srejović, Neca Jovanov, Kosta Čavoški, Mihailo Marković, Ljubomir Tadić, Ivan Janković, Nikola Milošević, Mića Popović, Antonije Isaković, Matija Bećković, Tanasije Mladenović, Andrija Gams, Gojko Nikoliš, Radovan Samardžić, Dimitrije Bogdanović i Predrag Palavestra. Kasnije su pridodati Zagorka Golubović, Vojislav Koštunica, Vesna Pešić i Enriko Josif. Od intelektualaca van Srbije osnivanje Odbora su podržali samo Rudi Supek i Taras Kermauner. J. Dragović Soso, n. d., 94-95, 99-100, 262-263; Odbor za zaštitu slobode misli i izražavanja, prir. Kosta Čavoški (Beograd: Službeni glasnik, 2009); Odbor za odbranu slobode misli i izražavanja. Dokumenti i saopštenja 19841986 (Beograd: M. Bećković dr., 1986). 
mnoštvo novih nezavisnih organizacija (Fond solidarnosti 1986, jugoslovenski ogranak Međunarodne helsinške federacije oktobra 1987, Jugoslovenski forum za ljudska prava 1988) i organizovan je niz akcija, peticija, protestnih večeri i drugih aktivnosti (u kojima su učestvovali i studenti) usmerenih na odbranu građanskih prava i sloboda, uvođenje političkog pluralizma i pružanje podrške optuženim za političke delikte, Srbima na Kosovu, itd. ${ }^{41}$

\section{IZVORI I LITERATURA}

- Arhiv Jugoslavije (AJ), fond 110 Državna komisija za utvrđivanje zločina okupatora i njihovih pomagača; 130 SIV; 212 Vrhovni sud Jugoslavije; 507 CK SKJ; 803 Predsedništvo SFRJ; 837 Kabinet Predsednika Republike

- Arhiv Srbije (AS), fond 200 Beogradski univerzitet.

- Dokumenti (jun-lipanj) 1968. Zagreb: Praxis, 1971.

- Študentsko gibanje 1968-1972. Prir. Ciril Bašković, et al. Ljubljana: RK ZSMS, 1982.

- Odbor za odbranu slobode misli i izražavanja. Dokumenti i saopštenja 19841986. Beograd: M. Bećković i dr., 1986.

- Beogradski univerzitet i '68. Zbornik dokumenata o studentskim demonstracijama. Priredili Momčilo Mitrović i Dobrica Vulović. Beograd: CMU, 1989.

- Šezdeset osma - lične istorije. Priredio Đorđe Malavrazić. Beograd: RTS, Službeni glasnik, 2008.

- Odbor za zaštitu slobode misli i izražavanja. Priredio Kosta Čavoški. Beograd: Službeni glasnik, 2009.

- Bela knjiga 1984. Obračun sa „kulturnom revolucijom“ u SFRJ. Priredili Srđan Cvetković, Kosta Nikolić i Đoko Tripković. Beograd: Službeni glasnik, 2010.

- Svedočenje arhitekte Predraga Ristića iz Beograda, dato S. Cvetkoviću septembra 2004. u Beogradu.

- Svedočenje Dragomira Olujića Oluje, Beograd 15. maj 2008.

- „Svedočenje Srđe Popovića“, TV-dokument, Pravila službe, B 92, 5. oktobar 2008.

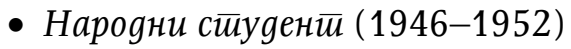

- НИН (1951-1990)

- Student (1953-1990)

${ }^{41}$ J. Dragović Soso, n. d., 103-104. 


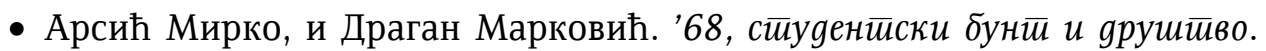
Београд: ЦМУ, 1985.

- Bondžić, Dragomir. Beogradski univerzitet 1944-1952. Beograd: ISI, 2004.

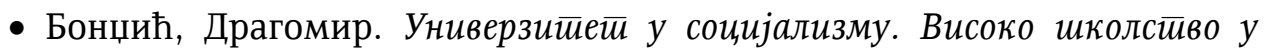
Србији 1950-1960. Београд: ИСИ, 2010.

- Bondžić, Dragomir. „Pisanje jugoslavenske i strane štampe o studentskim demonstracijama u Zagrebu i Skopju u svibnju 1959“. Historijski zbornik, br. 2, (2011), 499-514.

- Bondžić, Dragomir. „Protesty studentow w Polsce w marcu 1968 roku perspektywa jugoslowianska“. In: Polska i Jugoslawia po II wojnie swiatowej, pod redakcja Momčilo Pavlovicia, Nebojšy Stamboliji, Andrzeja Zaćminskiego, 201-212. Bydgoszcz: Instytut Historii i Stosunkow Miedzynarodowych UKW, 2016.

- Bošković, Milo. Antijugoslovenska fašistička emigracija. Novi Sad: Sloboda, 1980.

- Cvetković, Srđan. Između srpa i čekića II. Beograd: Službeni glasnik, 2011.

- Cvetković, Srđan. Između srpa i čekića III. Beograd: ISI, 2012.

- Dimitrijević, Bojan. „Odjek Brionskog plenuma na Službu unutrašnjih poslova 1966-1970“. Istorija 20. veka, br. 2, (2001), 75-88.

- "Disidentska skrivalica“, Republika, br. 242-243, (2000) http://www.yurope. com/zines/ republika/arhiva/2000/242-243/242243_21.html

- Драгнић, Алекс. Тийова обећана земља Јуі̄ославија. Београд: Чигоја штампа, 2004.

- Dragović, Soso Jasna. Spasioci nacije. Intelektualna opozicija Srbije i oživljavanje nacionalizma. Beograd: Fabrika knjiga, 2004.

- Ђорђевић, Димитрије. Ожиљии и ойомене, III. Београд: СКЗ, 1999.

- 1968 - četrdeset godina kasnije. Urednik Radmila Radić. Beograd: INIS, 1968.

- Крстић, Угљеша. Нейристиајање. Београд: Вајат, 2004.

- Mark, James, Peter Apor, Radina Vučetić, and Piotr Oseka. „'We are with you Vietnam': Transnational Solidarities in Socialist Hungary, Poland and Yugoslavia“. Journal of Contemporary History, vol. 50, no. 3 (2015), 439464.

- Marković Dragan, i Savo Kržavac. Liberalizam od Đilasa do danas, Pokušaj likvidacije SKJ i nova levica. Beograd: Sloboda, 1978.

- Марковић, Предраг Ј. Беоі̄pag између Исӣока и Зайаga 1945-1965. Београд: Службени лист СРЈ, 1996. 
- Marković, Predrag J. „Služba državne bezbednosti i albanske demonstracije na Kosovu 1968. godine: jedan dokument". Istorija 20. veka, br. 1/2 (1999), 169-180.

- Marković, Predrag J. „Najava bure: studentski nemiri u svetu i Jugoslaviji od Drugog svetskog rata do početka šezdesetih godina“. Tokovi istorije, br. 3-4 (2000), 51-62.

- Митровић, Момчило. „Резолуција ИБ и студенти Београдског универ-

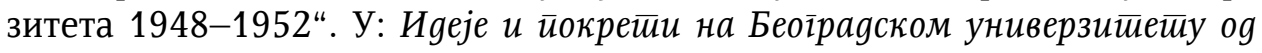
оснивања gо gанас, II. Уредници Мирољуб Васић и др., 245-253. Београд: Центар за марксизам Универзитета, 1989.

- Pavlović, Živojin. Ispljuvak pun krvi. Novi Sad: Prometej, 1999.

- Pekić, Borislav. Godine koje su pojeli skakavci III. Beograd: BIGZ, 1991.

- Petrović, M. „Kotrljanje glave od kaldrme do asfalta“. Njusvik, br. 67, 30. 5. 2016.

- Petrović, Vladimir. „Ekstremizacija jugoslovenskog političkog govora od smrti Josipa Broza do Osme sednice“. U: Slobodan Milošević - Put ka vlasti, Osma sednica CK SKS. Urednici Momčilo Pavlović, Dejan Jović, Vladimir Petrović, 80-97. Beograd: Institut za savremenu istoriju, 2009.

- Popov, Nebojša. Contra fatum: slučaj grupe profesora Filozofskog fakulteta u Beogradu 1968-1988. Beograd: Mladost, 1990.

- Popov, Nebojša. Društveni sukobi - izazov sociologiji. Beogradski jun 1968. Beograd: Službeni glasnik, 2008.

- Popović, Srđa. Poslednja instanca I. Beograd: Helsinški odbor za ljudska prava u Srbiji, 2003.

- Radelić, Zdenko. Hrvatska u Jugoslaviji 1945-1991 - od zajedništva do razlaza. Zagreb: Hrvatski institut za povijest, 2006.

- Simić Pero, i Zvonimir Despot. Tito, strogo poverljivo. Beograd: 2010.

- Spehnjak Katarina, i Tihomir Cipek. „Disidenti, opozicija i otpor: Hrvatska i Jugoslavija, 1945-1990“. Časopis za suvremenu povijest, 2 (2007), 255297.

- Spehnjak, Katarina. „Disidentstvo kao istraživačka tema - pojam i pristupi“. U: Disidentstvo u suvremenoj povijesti. Urednici Nada Kisić Kolanović, Zdenko Radelić, Katarina Spehnjak, 1-15. Zagreb: Hrvatski institut za povijest, 2010.

- Stanković, Đorđe. „Pobuna gladnih među gladnima“. Borba, br. 156, 5. 6. 1991, 16.

- Stanković, Đorđe. „Strana propaganda u postocima“. Borba, br. 157, 6. 6. 1991, 12.

- Станковић, Ђорђе. „Побуна гладних међу гладнима - студентске демонстрације у Београду 1954. године“. У: Изазов нове исйорије, 1, 188201. Београд: Војноиздавачки и новински центар, 1992. 
- Станковић Ђорђе, и Љубодраг Димић. Исйориоірафија йоg наgзором, 1. Београд: Службени лист СРЈ, 1996.

- Станковић, Ђорђе. „Студентске демонстрације у Београду 1954“. Сйу-

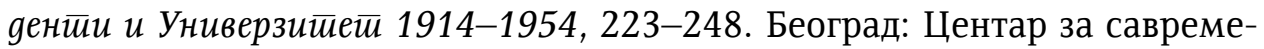
ну историју Југоисточне Европе, 2000.

- Šeks, Vladimir. Delikt mišljenja. Osijek: V. Šeks, 1986.

- Vučetić, Radina. „Violence against the antiwar demonstrations of 19651968 in Yugoslavia: political balancing between East and West". European History Quarterly, vol. 45, no. 2 (April 2015), 255-274.

- Zečević, Slavko. Sećanja i kazivanja. Beograd: Publikum, 2004.

Srđan Cvetković

Dragomir Bondžić

FORMS OF STUDENT RESISTANCE TO THE COMMUNIST REGIME IN SERBIA 1945-1990

\section{Summary}

This text is intersection and analysis of all forms of the student resistance to regime in Serbia since 1944 until 1990. The resistance to revolutionary government was destroyed by repression in first few years after Second World War and hushed during ' 50 s. After second half of ' 60 s it culminated, particularly in years after Tito's death. The highest intensity of active societal resistance in self-mana-gement socialism was reached in period 1966-1972 and after that 1982-1990. In the end of 60's new postwar generations were looking for their own political direction. Radical student movements and demonstrations, turbulences in the world were spilling over and raising political temperature in the country. This tendency coincided with campaign of liberalization after 1966 (fall of Aleksandar Ranković) and relative declining authority of the state, party and security services and the death of Josip Broz Tito as the main pillar of the regime. Global crises of communism in the ' 80 s and increasing economic crisis in SFRY was strengthening the intensity of resistance.

KEYWORDS: communism, students, Serbia, public protests, demonstrations, strikes, rebellions 


\section{ФОРМИ СОПРОТИВЛЕНИЯ СТУДЕНТОВ К КОММУНИСТИЧЕСКОМУ РЕЖИМУ В СЕРБИИ 1945-1990}

\section{Резюме}

Этот текст естъ сечение и анализ всех форм сопротивления студентов к режима в Сербии с 1944 по 1991 год. Сопротивление революционное правительство репрессии, которые уничтожили в первые годы после Второй мировой войны был приглушен в течение 50-их и после второй половины 60-их, кульминационный особенно в первые годы после смерти Тита. Наибольшая интенсивность сопротивления активном обществу в самоуправляющегося социализма был достигнут в период 1966-1972, а затем 1982-1991. В конце 60-их новыу поколения приходит после войны поисках своего собственного политического направления. Восстание многих послевоенного поколения радикальных движений студентов и демонстраций, турбулентности в мире (войны и террор эффект) с эффектом «огненных шаров» подняли температуру в стране. Кроме того, генерация восстания, либерализация кампании после того, как 1966 году в соответствии с этими процессами (накладка Ранкович) и относительного снижения авторитета государства, партии и служб безопасности, а также смерти Иосипа Броз в качестве главной основы режима. Положительное влияние на интенсивность сопротивления был глобальный кризис коммунизма в 80-е годы, а также растущего экономического кризиса в Югославии.

КЛЮЧЕВЫЕ СЛОВА: коммунизм, студенты, Сербия, общественные протесты, демонстрации, забастовки, бунты 